\title{
IMPLEMENTASI STANDAR PEMBELAJARAN \\ KITAB BERBAHASA ARAB DI PESANTREN Studi Kasus di Pondok Pesantren Madinatul IImi
}

\section{Badruzzaman *}

Balai Peneitian dan Pengembangan Agama Makassar Jl. AP.Pettarani No. 72 Makassar Email: bz69elzam@gmail.com

\begin{tabular}{|c|c|}
\hline INFO ARTIKEL & ABSTRAK \\
\hline $\begin{array}{r}\text { Kata Kunci: } \\
\text { Pembelajaran } \\
\text { Kitab, Kementerian } \\
\text { Agama, Pesantren }\end{array}$ & $\begin{array}{l}\text { Kementerian Agama telah mengaluarkan standarisasi kompetensi pengajian kitab } \\
\text { di pesantren sejak tahun 2009. Penelitian ini bertujuan untuk mengamati } \\
\text { implementasi kebijakan itu pada cakupan: kitab yang diajarkan, proses } \\
\text { pembelajaran, dan sistem evaluasi. Penelitian memperoleh data dari hasil } \\
\text { wawancara mendalam terhadap } 5 \text { (lima) orang informan kunci, dan menganalisis } \\
\text { data dengan metode analisis kualitatif. Penelitian menemukan bahwa Pondok } \\
\text { Pesantren Madinatul Ilmu (PP Madinatul Ilmu) belum mengimplementasikan } \\
\text { kebijakan Kementerian Agama tentang standarisasi kompetensi pengajian kitab. } \\
\text { Karenanya kegiatan sosialisasi kebijakan Kementerian Agama tentang } \\
\text { standarisasi kompetensi pengajian kitab perlu diintensipkan. Selain itu penelitian } \\
\text { juga menemukan bahwa sistem Taklim Idahfi (model pembelajaran kitab) di } \\
\text { pesantren diselenggarakan secara non formal. penyelenggaraan ini berimplikasi } \\
\text { pada penilaian hasil pembelajaran yang cenderung sumatif-evaluasi dilakukan } \\
\text { dalam rangka memberikan penambahan pemahaman dan keterampilan santri } \\
\text { membaca kitab. Karenanya diperlukan kajian pengembangan merumuskan } \\
\text { sistem pembelajaran dan evaluasi yang lebih baku agar penerapan standar } \\
\text { kompetensi pengajian kitab dapat optimal. }\end{array}$ \\
\hline
\end{tabular}

\section{ABSTRACT}

The Ministry of Religion of the Republic of Indonesia has established competency standards in studying Arabic books in Islamic boarding schools since 2009. This research aims to observe the implementation of policies within the scope of the books being taught, the learning process, and the evaluation. This study obtained data from in-depth interviews with 5 (five) key informants and analyzed the data using qualitative analysis methods. This study found that Madinatul Islamic Boarding School has not fully implemented the Ministry of Religion's policy on the standardization of learning competencies in Arabic books. Therefore, the Ministry of Religion needs religious competence to promote socialization. In addition, this study also found that Taklim Idahfi (a

Keywords: Arabic Book learning, Ministry of religion, Boarding school learning model) at Islamic Boarding Schools was held informally. This implementation has implications for the assessment of learning outcomes that tend to be summative - evaluations are carried out to provide additional understanding and teaching skills for reading Arabic books. Therefore studies need to be developed to formulate a more standardized learning and evaluation system for the application of competency standards for the study of Arabic books.

\section{PENDAHULUAN}

Pesantren merupakan pusat pendalaman ilmu-ilmu agama Islam (tafaqquh fiddin). Lembaga pendidikan Islam tertua di Indonesia telah banyak berperan mempersiapkan kader-kader ulama, dai, mubalig, ustaz yang sangat dibutuhkan masyarakat. Ciri khas utama pondok pesantren adalah penyelenggaraan program kajian kitab kuning (kutub atturats yang memuat ilmu-ilmu agama Islam. Namun dewasa ini pemanfaatan (kutub at-turats) sebagai sumber rujukan primer mulai berkurang, sehingga ditemukan beberapa alumni pesantren yang 
tidak mendalami ilmu-ilmu agama Islam dari sumber-sumber utamanya.

Dalam pesantren tradisional, penentuan kitab mana yang akan dikaji diserahkan kepada santri itu sendiri, kiai atau pesantren tidak secara ketat menentukan kitab tertentu yang wajib dikaji. Hal disebabkan oleh karena tradisi nyantri oleh para santri dilakukan secara berpindah-pindah. Beberapa kitab tertentu yang telah dikaji di pesantren sebelumnya tidak lagi dipilih untuk dikaji pada pesantren yang lain berikutnya. Para santri cenderung memilih kitab-kitab tertentu yang lain yang belum dikaji. Pemilihan tersebut mengindikasikan keterlibatan santri menentukan jenjang dan kurikulum belajarnya. Realitas ini dianggap oleh sebagian peneliti sebagai proses demokratisasi di dalam proses belajar mengajar di pesantren.

Proses belajar mengajar tersebut berimplikasi pada penentuan standar penguasaan santri terhadap kitab kuning. Setiap santri memiliki pengetahuan dan penguasaan terhadap kitab berbeda. Ada santri yang menguasai kitab fikih dan ada pula yang menguasai kitab tauhid, akhlak, atau tasawuf. Beberapa pesantren di Indonesia yang belum mengakomodasi sistem pendidikan nasional sebagai rujukan pengelolaan satuan termasuk proses pembelajaran (kurikulum). Satuan pendidikan tersebut membuat kurikulum tersendiri seperti dengan rujukan kitab berbahasa arab yang berbeda, sehingga pemerintah mengalami kesulitan untuk melakukan standarisasi penguasaan kitab santri. Sementara beberapa pesantren yang mengeluhkan dan menuntut agar ijazah yang dikeluarkannya diakui sama dengan sertifikat pendidikan formal lainnya sehingga dapat dijadikan persyaratan administratif untuk melanjutkan pendidikan atau melamar pekerjaan.

Pemerintah telah melakukan standarisasi pengajian kitab. Standarisasi ini tidak dalam rangka menghilangkan keragaman jenis pengajian kitab yang telah berlangsung berbeda di setiap pesantren.
Namun standarisasi ini dilakukan untuk kepentingan pembelajaran tuntas atau kemahiran (materi learning). Pondok pesantren sebaiknya memiliki standar kompetensi pengajian kitab, yaitu sejumlah kitab standar yang harus dikuasai oleh santri. Standar kompetensi ini dapat tercermin pada klasifikasi kitab-kitab, berdasarkan ringan sampai yang berat, dari kitab yang tipis sampai kitab yang berjilidjilid (Departemen Agama, 2009).

Dalam upaya itu, pemerintah dalam hal ini Direktorat Pendidikan Diniyah dan Pondok Pesantren Direktorat Jenderal Pendidikan Islam Kementerian Agama telah melakukan pengkajian bersama dengan sejumlah tokoh agama dan pimpinan pondok pesantren se Indonesia. Hasilnya adalah terdapat sejumlah kitabkitab standar yang diajarkan di pondok pesantren berdasarkan jenjang satuan pendidikan keagamaan, mulai dari tingkat Idadiyah, Ibtidaiyah, Tsanawiyah, maupun Aliyah. Kitab-kitab tersebut juga dijadikan kriteria penentuan standar kompetensi pembelajaran kitab di pesantren.

Upaya yang lain yang telah dilakukan oleh pemerintah adalah kegiatan-kegiatan kompetitif berkaitan dengan tingkat penguasaan santri terhadap kitab-kitab tersebut. Kegiatan Mushabaqah Qiraatil Kutub telah diselenggarakan secara periodik oleh Kementerian Agama RI, dalam upaya memberikan penyamaan persepsi tentang kitab-kitab tertentu yang wajib dikuasai oleh seorang santri berdasarkan jenjang pendidikannya. Kegiatan yang sama yang paling bergengsi dilakukan oleh Direktorat Pendidikan Agama Kementerian Agama RI pada tanggal 19-24 juli 211 di Pancoran Lombok Timur NTB. Kegiatan itu bertema Musabaqah Fahmi Kutubit Turats (MUFAKAT) Tingkat Nasional IV.

Mengamati implementasi kebijakan Direktorat Pendidikan Diniyah dan Pondok Pesantren Kementerian Agama adalah urgen. Urgensi itu dalam rangka mengevaluasi kecapaian tujuan kebijakan tersebut untuk bertujuan untuk menentukan 
standar pembelajaran Kitab Berbahasa Arab di beberapa lembaga pendidikan Islam, seperti pesantren.

Penelitian ini bertujuan untuk mengetahui implementasi standar pembelajaran kitab berbahasa Arab di Pondok pesantren Madinatul Ilmi. Implementasi pembelajaran yang dimaksu mencakup tentang jenis kitab yang ajarkan, sistem pembelajaran kitab, dan sistem evaluasi pembelajaran kitab.

\section{Kajian Pustaka}

Zamakhsyari Dhofir (1983: 49) mengidentifikasi elemen penting yang lainnya yaitu kitab-kitab yang ditulis oleh ulama Islam atau kitab kuning yang diajarkan di pesantren. Para santri harus dibekali dengan ilmu pengetahuan agama yang cukup, karena mereka calon pemimpin Islam. Seorang santri yang telah menguasai beberapa kitab kuning, maka ia kemudian di sebut kiai oleh masyarakat (Asrohah, 2004: 39). Pesantren dikenal sebagai pencetak kiai. Oleh karena itu, para calon kiai belajar atau mengaji kitab kuning di pesntren. Kitab-kitab Islam klasik dikarang para ulama terdahulu dan termasuk pelajaran mengenai macammacam ilmu pengetahuan agama Islam dan Bahasa Arab. Dalam kalangan pesantren, kitab-kitab Islam klasik sering disebut kitab kuning oleh karena warna kertas edisi-edisi kitab kebanyakan berwarna kuning. Menurut Zamakhsyari Dhofier (1983: 50), "pada masa lalu, pengajaran kitab-kitab Islam klasik....merupakan satu-satunya pengajaran formal yang diberikan dalam lingkungan pesantren." Dewasa ini, dominan pesantren telah mengintegrasikan pengajaran pengetahuan umum sebagai suatu bagian penting dalam pendidikan pesantren, namun pengajaran kitab-kitab Islam klasik masih diberi kepentingan tinggi. Ada delapan macam bidang pengetahuan yang diajarkan dalam kitabkitab Islam klasik, termasuk: fikih; usul fikih, nahu dan saraf (morfologi), hadis, tauhid, tafsir, tasawuf dan etika, serta cabang-cabang lain seperti tarikh dan balagah. Ahmad Syafi'i Mufid (2006: 113) menyatakan bahwa kitab-kitab kuning yang diajarkan di pesantren dapat dikelompokkan berdasarkan disiplin ilmu Islam adalah Quran/tafsir, hadis, bahasa Arab, fikih/usul fikih dan tasawuf/akhlak. Sementara Zamaksyari Dhofier mengelompokkan jenis kitab menurut tingkat ajarannya, misalnya: tingkat dasar, menengah dan lanjut. Kitab yang diajarkan di pesantren di Jawa pada umumnya sama (Dhofier, 1983: 51).

Dulu, pusat pembelajaran Islam diselenggarakan di rumah sang guru, masjid, atau langgar, secara halaqah dan pada waktu malam hari. Menurut Zuhairini, bahwa model penyelenggaraan pendidikan non formal inilah yang "menjadi embrio terbentuknya sistem pendidikan pondok pesantren." (Zuhaini, 1997: 212) Ini berarti bahwa sistem pendidikan pada pondok pesantren tidak mengalami perubahan yang sangat berarti, yang berubah hanya intensitas pembelajarannya dan dalam waktu yang lebih lama.

Sistem pengajaran di pondok pesantren dikenal dua jenis yaitu sistem sorogan, yang sering disebut sistem individual, dan sistem bandongan atau weton yang sering disebut kolektif. Sorogan berasal dari kata sorog (bahasa Jawa), yang berarti menyodorkan atau menyerahkan. Dalam kenyataannya, sorogan diterapkan dengan cara setiap santri menyodorkan kitab kajiannya di hadapan kiai atau asisten kiai, untuk selanjutnya sang kiai atau asistennya mengajar santri yang bersangkutan berdasarkan kitab yang disodorkan itu. Bandongan/weton, istilah weton ini berasal dari kata wektu (bahasa Jawa) yang berarti waktu. Penamaan metode ini mengikuti praktik nyata terjadinya pembelajaran dimaksud. Istilah Weton ini di Jawa Barat disebut dengan bandungan. Sistem sorogan diterapkan untuk membimbing santri-santri yang telah menguasai kitab-kitab yang sulit dipahami, karenanya harus dibimbing langsung oleh kiai atau pembantu kiai. Zamakhsyari 
Dhofier menyatakan bahwa santri sudah harus mengalami tingkat sorogan ini sebelum dapat mengikuti pendidikan selanjutnya di pesantren (Dofier, 1983: 51). Sistem pengajaran di pesantren mulanya tidak dengan klasikal. Menurut M. Sarijo yang dikutip oleh Azhar Arsyad (2012), bahwa pesantren-pesantren pada mulanya tidak mengenal sistem klasikal. Sistem sorogan juga digunakan di pondok pesantren tetapi biasanya hanya untuk santri baru yang memerlukan bantuan individual.

Sistem pembelajaran yang lain adalah bandongan atau weron. Sistem ini biasanya diterapkan di lingkungan pesantren. Sekelompok murid mendengarkan seorang guru yang membaca, menerjemahkan, dan menerangkan buku-buku Islam dalam bahasa Arab. Kelompok kelas dari sistem bandongan ini disebut halaqah yang (menurut Zamakhsyari Dhofier) artinya sekelompok siswa yang belajar dan dibimbing oleh seorang guru (Dhofier, 1983: 28), sementara Azhar Arsyad membagi varian sistem dan metodologi pembelajaran konvensional yang dianut pesantren, yaitu: sorogan, weton/bandongan, halaqah dan tahfiz (Arsyad, 2012). Halaqah arti bahasanya "lingkaran murid", atau sekelompok siswa dengan formasi duduk melingkar, belajar di bawah bimbingan seorang guru atau belajar bersama dalam satu tempat. Metode tahfiz yang diterapkan untuk menghafal kitabkitab tertentu, termasuk Alquran dan Hadis Biasanya santri ditugaskan menghafal beberapa bait dari kitab, dan setelah beberapa hari baru dibacakan di depan kiai/ustaz. Dalam pengembangan metode tahfiz ini, pola penerapannya tidak hanya menekankan hafalan teks dengan berbagai variasinya, tetapi harus juga melibatkan ranah intelektual sampai kepada comprehension (pemahaman), analisis, dan evaluasi (Arsyad, 2012).

Pesantren sekarang terdiri atas dua dua macam, yaitu pesantren tradisional dan pesantren modern. Pesantren tradisional sering disebut sistem salafi. Pesantren yang tetap mempertahankan pengajaran kitabkitab Islam klasik sebagai inti pengajaran. Pondok pesantren modern merupakan sistem pendidikan yang memadukan secara penuh sistem tradisional dan sistem sekolah formal (seperti madrasah).

Proses modernisasi pondok pesantren bertujuan untuk menyempurnakan sistem pendidikan Islam yang ada di pesantren. Akhir-akhir ini pondok pesantren mempunyai kecenderungan baru untuk mengakomodasi perkembangan ilmu pengetahuan dan teknologi dalam rangka renovasi terhadap sistem yang selama ini dipergunakan. Menurut Hasbullah (1999: 155), bahwa perubahan-perubahan yang bisa dilihat di pesantren modern termasuk: mulai akrab dengan metodologi ilmiah modern, lebih terbuka atas perkembangan di luar dirinya, diversifikasi program dan kegiatan di pesantren makin terbuka dan luas, dan sudah dapat berfungsi sebagai pusat pengembangan masyarakat.

\section{METODE PENELITIAN}

Sasaran penelitian adalah Pondok Pesantren Madinatul Ilmi (PP Madinatul Ilmu). Penentuan sasaran ini berdasarkan pertimbangan, bahwa PP Madinatul Ilmu berada yang dibawah binaan Alkhairat, merupakan organisasi sosial keagamaan yang tertua di Sulawesi Tengah dan berkembang di hampir seluruh propinsi kawasan Indonesia tengah dan timur, didirikan oleh Habib Idrus Bin Salim Aljufri.

Data primer penelitian dikumpulkan dengan mewancarai secara mendalam 5 (lima) orang informan tentang proses pembelajaran kitab berbahasa Arab di Pesantren Madinatul Ilmi. Sementara data sekunder yang berkaitan dengan perkembangan pesantren diperoleh dengan cara mengumpulkan arsip persuratan, laporan bulan pesantren, dan beberapa tulisan berkaitan dengan sejarah Pondok Pesantren Madinatul Ilmi. Analisis data dilakukan dengan metode analisis kualitatif, dengan tahapan: identifikasi data, klasifikasi data, memilih data yang sesuai 
dengan tujuan penelitian dan menyisihkan yang tidak sesuai, melakukan sintesis data yang telah diklasifikasi berdasarkan kategori penelitian, kemudian menyimpulkan.

\section{TEMUAN PENELITIAN}

\section{Profil Pondok Pesantren}

Pondok Pesantren Madinatul Ilmi merupakan salah satu satuan pendidikan yang bernaung di bawah atau dalam pengelolaan Perguruan Islam Alkhairat/Yayasan Alkhairat. Pondok Pesantren terletak di Jl. Palu Kulawi KM 11 Desa Kotarindau Kec. Dolo Kabupaten Sigi Sulawesi ini didirikan pada tahun 1992 oleh H.S. Saggaf Al Jufri. Semula didirikan dengan maksud untuk menanggulangi kekurangan tenaga pengajar yang profesional di madrasah. Ketua Utama Alkhairat, H.S. Saggaf Al Jufri, mengamati bahwa madrasah di Sulawesi Tengah sangat membutuhkan tenaga pengajar yang profesional. Gagasan untuk menghadirkan pondok pesantren merupakan salah satu butir pemikiran H.S. Saggaf Al Jufri yang disampaikan pada Muktamar Besar Alkhairat VII tahun $1991 \mathrm{M} / 1412 \mathrm{H}$. Pemikiran ini didasari oleh semakin sulitnya mencari tenaga pengajar tingkat dasar pada madrasah yang memiliki kemampuan intelektual yang cukup, terutama pada madrasah dibawah binaan Perguruan Islam Alkhiraat. Harapan ini menjadi impian sehingga Perguruan Islam Alkairaat dapat menjalankan fungsinya sesuai amanat pendiri Alkhairaat Habab Idrus Bin Salim Aljufri.

Pondok Pesantren Madinatul Ilmi menaungi beberapa pendidikan formal, yaitu Raudatul Atfal (RA), Madrasah Ibtidaiah (MI), Madrasah sanawiah (MTs), Madrasah Aliah (MA), dan SMK. Raudhatul Athfal Madinatul Ilmi didirikan pada tahun 1989, dan saat ini dipercayakan kepada Hj. Rosno Jalidjama, A.MA sebagai kepala RA. Madrasah Ibtidaiyah Madinatul Ilmi didirikan pada 1985, dan Urwah, S.Ag. sebagai kepala madrasah. Madrasah
Tsanawiyah Madinatul Ilmi didirikan pada tahun 1995, dan saat ini dipimpin oleh Jibran, S.Ag. Madrasah Aliyah Madinatul Ilmi didirikan pada tahun 1992 dan Drs. Anwar Nurullah, S.Ag. sebagai kepala madrasah. Sementara SMK didirikan pada tahun 2005 dan kepala sekiolah adalah Gandong, S.Pd. M.Pd.

Jumlah tenaga pengajar PP Madinatul Ilmi cukup banyak. Terdapat sejumlah 108 orang guru yang mengajar di semua jenis dan jenjang satuan pendidikan di bawah naungan PP Madinatul Ilmi, yaitu RA, MI, MTs, MA dan SMK. Namun bila diamati pada setiap jenjang dan jenis satuan pendidikan, jumlah guru itu masih tergolong kurang. Beberapa mata pelajaran masih dirangkap oleh seorang guru, seperti mata pelajaran yang serumpun. Dominan tenaga pengajar bertugas secara resmi di satuan pendidikan negeri seperti SMU atau MAN - guru mata pelajaran umum -- dan diminta untuk mengajar di pesantren dengan imbalan yang kurang memuaskan. Karenanya terkadang proses pembelajaran yang telah dijadwalkan terganggu karena keterlambatan atau ketidakhadiran guru untuk mengajar.

Kurikulum pengajaran yang diterapkan di PP Madinatul Ilmi menggabung tiga kurikulum, yaitu kurikulum yang dikeluarkan oleh Kementerian Agama, Kementerian Pendidikan Nasional, dan Yayasan Alkhairat. PP Madinatul Ilmi mengakomodasi kurikulum Kementerian Agama dalam rangka mengikuti program pendidikan dan pengajaran agama pemerintah dimana mata pelajarannya mencakup 5 mata pelajaran agama, sedangkan kurikulum yang dikeluarkan oleh Kementerian Pendidikan Nasional diakomodasi dalam rangka memberikan pengetahuan umum, pengetahuan alam, dan pengetahuan sosial kepada santri sebagai mana di sekolah umum. Sementara kurikulum yang dikeluarkan oleh Yayasan Alkhairat diarahkan kepada penguasaan santri terhadap ilmu agama dan keagamaan, termasuk penguasaan terhadap bahasa arab 
-- baik lisan maupun tulisan, kitab-kitab berbahasa Arab dan menghafal Al Qur'an dan Al Hadist.

Secara umum, sistem pembelajaran di PP Madinatul Ilmi menggunakan dua jenis, yaitu sistem pembelajaran secara formal dan non formal. Sistem pembelajaran formal dilakukan secara klasikal di setiap jenjang pendidikan, baik di RA, MI, MTs, MA dan SMK dilaksanakan pada pukul 07.00-12.00. Sementara sistem pembelajaran non formal dilakukan dalam bentuk Taklim Idhafi, dilaksanakan pada sore hari, setelah shalat Ashar.

Santri PP Madinatul Ilmi terdiri atas santri mukim dan tidak mukim. Santri mukim adalah santri yang diharuskan bermukim di pondok pesantren. Berdasarkan aturan kepesantrenan Madinatul Ilmi, santri yang belajar pada jenjang MTs dan MA ditetapkan sebagai santri mukim, sedangkan santri yang belajar pada jenjang pendidikan RA, MI, dan SMK, ditetapkan sebagai santri tidak mukim.

Penerimaan santri di PP Madinatul Ilmi dilaksanakan secara fleksibel. Santri yang diterima di setiap jenjang satuan pendidikan tidak diisyaratkan harus dari tamatan madrasah atau satuan pendidikan agama serupa. Pada tingkat MI, santri yang diterima tidak diisyaratkan dari tamatan RA atau TK. Demikian halnya dengan santri yang diterima di tingkatan MTs, dan MA, dapat dari sekolah umum maupun madrasah. Fleksibilitas serupa juga diterapkan pada siswa yang tamat pada setiap jenjang pendidikan di PP Madinatul Ilmi. Santri yang tamat di RA diberikan kebebasan untuk melanjutkan pendidikan di satuan pendidikan mana saja, baik pada satuan pendidikan yang dibina oleh Perguruan Islam Alkahirat maupun sekolah umum lainnya. Hal serupa pada santri yang tamat pada jenjang pendidikan MI, MTs, dan MA.

Jumlah santri PP Madinatul Ilmi sekarang mencapai 651 orang. jumlah tersebut tersebar di lima satuan pendidikan formal yang berada dalam lingkungan PP Madinatul Ilmi. Santri yang bermukim di pesantren hanya santri MTs dan MA, sendengkan selainnya tidak diwajibkan bermukim.

Pondok Pesantren Madinatul Ilmi berdiri diatas tanah seluas 40 hektar. Tanah seluas tersebut dibangun berbagai fasilitas pendidikan, seperti gedung perkantoran, kelas, masjid, asrama, aula, bahkan sampai pada toko. Sarana dan prasarana yang menjadi fasilitas pendukung proses belajar mengajar di PP Madinatul Ilmi cukup lengkap.

Secara umum fasilitas pendidikan PP Madinatul Ilmi terdiri atas asrama santri, ruang kelas, masjid, kantor pesantren swalayan mini, areal pertanian, kolam pemeliharaan ikan, gedung Balai Latihan Kerja Pertukangan Kayu (BLK), perpustakaan, laboratorium komputer, laboratorium bahasa dan lain-lain. Fasilitas-fasilitas tersebut terbagi ke setiap satuan pendidikan PP Madinatul Ilmi.

\section{Kitab yang Diajarkan}

Kitab-kitab berbahasa Arab yang diajarkan di PP Madinatul Ilmi terdiri atas kitab yang pembahasannya berkaitan dengan bahasa Arab (nahwu dan sharf), Tauhid, Fikih, Tasawuf dan Hadis.

Ada sejumlah 10 kitab Nahu yang dijadikan rujukan dalam dalam pembelajaran kitab berbahasa Arab di PP Madinatul Ilmi, yaitu : a) Matan alJurumiyah, dikarang oleh Imam Shanhaji. b) Syarah Al Allama Syeikh Hasan Kafrawi terhadap Matan al-Jurumiyah. c) AlKawakib al-Darriyah, dikarang oleh Al Alim Allama Syeikh Muhammad Ibn Ahmad Ibn Abdu Baariy Al Ahdal. d) Jaami' al-Durusu al-Arabiyah, Jilid 1-3, dikarang oleh Ta'lif Syeik Musthafah Algulaayiiniy. e) Tuhfat al-Ahbaabi wa Thurfau al-Ashaabi, dikarang oleh Al Imam Allama Syiehk Muhammad ibnu Muhammad 'Amir Bahruqi Al Hadhramy. f) Tashiil al-Niilu al-Maaniy, dikarang oleh Syeikh Abdul Qaahar Al Jarjaamiy. g) Haasyiyat al-Alaamat al-Haqqiq ala Matan al-Jurumiyah, dikarang oleh Imam Khaalid Al Azhary. h) Al Khariidat al-Bahiyyat fii 
I'raabi al Faadh al-Jurumiyyah, dikarang oleh Abdullah Ibnu Utsman Almakiy. i) Syarah Syazhuur al-Zhahbi fii Mu'arrafat al-Kallami al-Arabi, dikarang oleh Imam AL Muhaqqiq Jamaluddin Ibu Muhammad Abdullah Ibu Syeikh Jamaluddin Yusuf Ibnu Ahmad Ibnu Abdullah Ibnu Hasyim Al Anshory. j) Syarah Mukhtashur Jad, dikarang oleh Imam Al Shanhaajiy.

Kitab-kitab yang berkaitan dengan ilmu Sharaf adalah : a) Matan al-Banaa' wa al-Asaas, dikarang oleh Imam Malaa Abdullah Addanqaziy rahimahu llah. b) Kitab Syazhl al-Uruf, dikarang oleh Ta'liif Al Ustaadz Syeikh Ahmad Aljamalaawiy. c.) Kitab Al-Tashriif, dikarang oleh Hasan Ibnu Ahmad d) Mu'jam Qawaaid al-Lugat al-Arabiyah, oleh Dr. Jurjuj Matriy Abdul Masih.

Sementara kitab-kitab yang berkaitan dengan Fiqhi adalah sebagai berikut: a) Matan al-Gaayah wa al-Taqriib b) Syarah Fathu al-Qariib, dikarang oleh Imam Allama Ahmad Ibnu Al Husain. c) AlTaqzib, dikarang oleh Ta'llif Dr. Musthafa Raibu Baqaa.

Dan kitab-kitab yang berkaitan dengan Hadist adalah: a) Al-Mawaa'izhu al-'Ashwariyyah, dikarang oleh Syeikh Muhammad Ibnu Abi Bakar Al Masyhuuri bi Ashfuuriy. b) Al-Azkaar. c) Nashaaizu al-'Ibaad, dikarang oleh Syeik Muhammad Nawawy Ibnu Umar Al Jawy. Ta' Liif Syahaabuddin Aihmad Ibnu Hajar Al 'Asqalaaniy. d) Al-Nashaaihu al-Diniiyah wa al-Washaaya al-Imaaniyah, dikarang oleh Syeikh Al Imam barkatul anaam Abdullah Ba'lawy Al Haddad.

Pada tingkat MTs, kitab-kitab yang wajin dikuasai oleh santri adalah Matan alJurumiyah (Kitab Nahwu) dan Matan al Binaai wa al-Asaasi (Kitab Sharaf), Akhlaku li al-Banin Jilid 1, 2 dan 3 (Kitab Akhlak), Sullamu al-Tauhid Jilid 1, 2, dan 3 (Kitab Tauhid), Mabaadiu al-Fiqhiyah (Kitab Fikih). Sedangkan pada tingkat MA, kitab-kitab yang wajib dikuasai oleh santri adalah : Syarah Matan al-Jurumiyah, Syarah Matan al-Binaai wa al-Asaasi, Fiqhu al-Qariib, Riyaadhu al-Shaalihin,
Husnu al-Hamidiyah (Kitab Tauhid), Nashaarihu al-Diin, Nashaarihu al-Adab, dan Ihyaau al-Ulumu al-Diin. Kitab-kita selainnya - kitab yang tidak diwajibkan untuk dikuasai --, menjadi kitab tambahan atau pengayaan bagi ustaz dalam menjelaskan kitab wajib tersebut.

\section{Proses Pembelajaran Kitab Berbahasa Arab}

Dua metode pembelajaran kitab berbahasa Arab yang telah dibiasakan di pondok pesantren pun diterapkan di PP Madinatul Ilmi. Metode bandongan dilakukan setiap sore hari secara klasikal. Semua santri mendengarkan ustaz menjelaskan maksud kandungan kitab. Sementara seluruh santri turut menyimak penjelasan tersebut. Metode sorogan pun diterapkan dalam proses pembelajaran kitab berbahasa arab. Bentuknya berupa beberapa santri (biasanya terdiri atas tiga sampai 5 orang santri) mendatangi ustaz dengan membawa kitab yang berbeda. Kitab yang dibawa oleh santri itu berdasarkan kecenderungan masing-masing. Seperti ada santri yang membawa kitab yang memuat pembahasan bahasa, fikih, hadis, atau akhlak.

Khusus berkaitan dengan metode sorogan, santri menghadap ke salah seorang ustaz dengan membawa masingmasing kitab yang digemarinya. Di depan ustaz mereka diminta untuk membaca satu persatu, sementara ustaz menyimak bacaan dan mengamati kesalahan-kesalahan dalam bacaan. Bila terdapat kesalahan, maka ustaz meminta santri yang lain untuk membetulkan dengan mengungkapkan seperti kedudukan kata yang salah, seperti mubetada, (pengertian, nahwu, i'rab, dan tashrif-nya). Demikian yang secara berulang, sampai semua santri mendapat giliran membaca.

Proses pembelajaran kitab pada tingkat MTs dan MA dominan dilakukan terpisah terutama bila menggunakan metode bandongan. Pada masing-masing tingkatan tersebut telah disusun jadwal yang disebut dengan "Jadwal Ta'lim 
Idhafi". Ta'lim Idhafi dilakukan setiap hari belajar kecuali hari libur (Hari Jumat). Dalam sehari dijadwalkan hanya satu kegiatan taklim.

Tidak semua siswa MTs diwajibkan mengikuti Ta'lim Idhafi. Kegiatan ini hanya diwajibkan kepada siswa kelas VII dan kelas VIII. Hal ini dilakukan dengan pertimbangan bahwa kelas IX membutuhkan waktu dan perhatian yang banyak menghadapi Ujian Akhir Nasional.

Selain pembelajaran kitab berbahasa Arab, pembelajaran Bahasa Inggeris dan Qiraatul Qur'an juga dimasukkan dalam kegiatan Ta'lim Idhafi. Ada beberapa mata pelajaran jenis mata pelajaran yang diajarkan pada Ta'lim Idhafi, yaitu, pada kelas VII mata pelajaran yang diajarkan adalah Bahasa Inggeris, Qiraatul Qur'an, dan Muhaawarah/Muhadasah. Sementara pada kelas VIII mata pelajaran yang diajakan adalah Nahwu, Muhaawarah/Muhadasah, dan Sharaf. Kitab-kitab yang bermuatan itulah yang diajarkan dalam Ta'lim Idhafi.

Kitab-kitab yang diajarkan pada MTs masih bertaraf dasar, yaitu Matan alJurumiyah, Matan al-Bina wa al-Asaasi, AlAkhlak li al-Banin, dan Sullam alTauhiid. Sedangkan kitab-kitab yang membahas tentang Syarah diajarkan pada tingkat MA, seperti Syarah al-Jurumiyah, Syarah al-Binaa wa al-Asasi, Nashaarih alDin, Nashaarih al-Ibaadi, dan lain-lain.

Terdapat sejumlah 10 ustaz yang ditugaskan untuk mengajar pada kegiatan Ta'lim Idhafi pada tingkat MTs. Kesepuluh ustaz itu adalah 1) Aburrahman Adam, Sag, 2) Abdul Manan, S.HI., 3) Citrawan, LC, 4) Anwar, S.Pd.I, 5) Syarofi, 6) Hasnirwana, S.Pd., 7) Basnur, S.Pd. M.Pd., 8) Zulbahdar, 9) Asgar Karona, LC, dan 10) Anas Umar, LC.

Pada tingkat MA pembacaan kitab (qiraat al-kutub) sangat diintensipkan. Semua mata pelajaran yang diajarkan berdasar pada kitab-kitab berbahasa Arab. Mata pelajaran yang diajarkan adalah Nahwu, Akhlak, Hadis, Muhawarah dan Bahasa Inggeris. Pada mata pelajaran
Nahwu, kitab yang dijadikan rujukan utama adalah Syarah Dahlan dan Syarah alKafrawiy, pada mata pelajaran Akhlak kitab yang digunakan adalah Kitab Ta'limu al-Muta'allim dan Nashaarihu al-Diniyah, dan mata pelajaran Hadis kitab yang diajarkan adalah Riyadu al-Shaalihiin.

Pembagian secara klasikal pada kegiatan Ta'lim Idhafi dibagi seperti pada MTs. Kelas XII tidak lagi dibebankan untuk mengikuti kegiatan Ta'lim Idhafi, yang diwajibkan adalah santri yang masih duduk di kelas X dan XI. Demikian halnya dengan pembagian kitab yang dijadikan rujukan utama. Pada kelas X, Jurusan Bahasa, Jurusan IPA, kitab yang diajarkan secara intensif adalah Syarah Dahlan, Ta'lim alMuta'allim daa Riyadh al-Shaalihiin. Sementara pada Jurusan Keagamaan selain mempelajari ketiga kitab tersebut juga mempelajari kitab SyarahaAl-Kafrawiy, dan Nashaarih al-Diniyah.

Terdapat 12 orang ustaz yang ditugaskan untuk mengajar pada Ta'lim Idhafi MA. Keduabelas ustaz itu adalah 1) HS. Saggaf Aldjufrie, MA, 2) DR. Ali Aljufrie, LC, MA, 3) Drs. Anwar Nurullah, S.Ag. 4) Husen Salim Bachmid Lc, 5) Januar Rahman, S.Pd. 6) Anas Umar LC, 7) Abdul Haris S.Th.I, 8) Abdul Manan, S.HI, 9) Asgar Karona, LC 10) Muh Rexa, LC, 11) Citrawan, LC, dan 12 Nur Ilah, S.Pd.I.

Ustaz sangat memperhatikan tingkat penguasaan santri dalam memberikan tugas penjelasan. Seperti pengertian tentang khabar, maka yang diberikan tugas untuk menjelaskan adalah santri yang telah menguasai kitab-kitab matan. Sedangkan penjelasan yang lebih detail tentang itu maka santri yang telah menguasai kitab syarah yang diberikan tugas.

Motivasi mempelajari kitab pun menjadi perhatian serius bagai ustaz. Ustaz sangat menjaga agar santri tidak minder akibat kesalahannya dalam membaca kitab. Karenanya bila hal itu terjadi maka ustaz pun memberikan motivasi agar tetap memperdalam kemahiran membaca kitab. 


\section{Evaluasi Hasil Belajar}

Evaluasi hasil pembelajaran Ta'lim Idhafi tidak dilakukan secara formal. Kegiatan evaluasi tidak dilakukan dengan penentuan standar penguasaan qiraat alqutub secara jelas yang nantinya dijadikan kriteria untuk mengukur tingkat penguasaan santri terhadap kitab-kitab yang diajarkan. Karenanya evaluasi hasil pembelajaran Ta'lim Idhafi tidak dijadwalkan seperti sistem evaluasi mata pelajaran yang lain baik di MTs maupun Ma.. Demikian halnya dengan pemberian nilai sebagai pencapaian daya serap dan tingkat prestasi santri pada mata pelajaran tersebut.

Hal ini disebabkan oleh ketetapan pesantren yang fleksibel terhadap kecenderungan dan minat santri terhadap penguasaan jenis kitab berbahasa Arab. PP Madinatul Ilmi tidak memberikan penekanan khusus kepada seluruh santri untuk menguasai kitab-kitab tertentu. Kebijakan ini berimplikasi kepada keragaman kecenderungan dan minat santri mendalami kitab-kitab berbahasa Arab. Terdapat santri yang kecenderungan mempelajari kitab-kitab tafsir, tauhid, hadis, ataupun akhlak.

Namun yang sangat ditekankan kepada santri adalah penguasaan terhadap kitab-kitab yang membahas tentang bahasa, seperti kitab-kitab Nahwu, Syaraf, dan Muharabah. Kitab-kitab semacam ini diajarkan secara formal yang terintegrasi pada kurikulum MTs dam MA. Karenanya sistem pengajarannya dilakukan baik pada kegiatan pembelajaran formal di MTs dan Aliah juga diajarkan dalam Ta'lim Idhafi.

Evaluasi penguasaan santri terhadap kitab berbahasa Arab dilakukan ketika pembelajaran dilakukan secara sorogan. Ketika santri diminta untuk membaca kitab yang diminatinya, maka evaluasi secara personal pun dilakukan oleh ustaz terhadap penguasaan santri kitab yang diminati. Ustaz dapat mengukur tingkat penguasaan santri terhadap kitab-kitab yang berbeda tersebut ketika masing-masing santri membaca kitab.
Ustaz tidak memberikan penilaian tertentu terhadap tingkat penguasaan santri. Ustaz tidak menetapkan indikator-indikator tertentu yang akan dijadikan alat ukur untuk memberikan prestasi belajar santri terhadap kitabnya. Karenanya tidak ada angka prestasi tertentu yang diperoleh santri terhadap proses pembelajaran itu.

Ustaz hanya melakukan penilaian yang tampak berorientasi sumatif. Ustaz memberikan penilaian terhadap penilaian santri dalam rangka memberikan pembelajaran baru untuk meningkatkan kemampuan dan penguasaan santri terhadap kitab yang diminati. Dan tujuan penilaian itu dapat dilakukan seketika itu, dengan memberikan penjelasan berkaitan dengan pemahaman santri terhadap kandungan kitab tersebut.

Yang ditekankan dalam proses penilaian itu adalah tingkat pemahaman santri terhadap maksud yang tercantum dalam kitab tersebut. Karenanya pertanyaan-pertanyaan ustaz terhadap santri dominan berkaitan dengan Qawaid, Nahwu, dan Syaraf. Ustaz selalu bertanya berkaitan dengan kandungan kitab-kitab Matan alJurumiyah, Matan al-Bina wa al-Asasi, Syarah al-Jurumiyah, Kitab Tashrif, dan Mu'jam Qawaid al-Lughah al Arabiyah.

Seperti ketika santri membaca kitabnya dan tiba pada kalimat tertentu. Kalimat itu dipahami maknanya dengan mendasarkan pada kitab-kitab tersebut di atas. Kalimat tersebut dianalisis berdasarkan kedudukan kata pada kalimat, baik dari aspek qawaid, nahu, maupun sharafnya. Apa yang dimakud mubetada, khabar, huruf dan lain-lain, bagaimana pengertiannya dalam nahwu baik pada kitab matan maupun kitab syarah, bagaimana perubahan katanya (tashrifnya), dan bagaimana pemaknaan dengan bentuk tashrif tersebut.

Dengan memahami seluruh aspek itu, maka pemahaman santri terhadap makna kalimat berbahasa Arab dalam kitab tersebut tepat dan benar. Tingkat ketepatan dan kebenaran pemahaman santri terhadap pembacaan kitab yang diharapkan dalam 
proses pembelajaran ini. Karenanya evaluasi secara sumatif lebih dominan dilakukan dari pada evaluasi formatif.

\section{PENUTUP}

Pondok Pesantren Madinatul Ilmi telah mengimplementasikan pembelajaran kitab berbahasa Arab. Implementasi tersebut didasarkan pada kebijakan Kementerian Agama RI berkaitan dengan standarisasi kompetensi pembelajaran kitab berbahasa Arab. Standarisasi kompetensi yang dimaksud terwujud pada jenis kitab yang diajarkan berdasarkan jenjang satuan pendidikan yang diselenggarakan oleh kedua pondok pesantren. Namun penerapan standar kompetensi pengajian kitab tampak belum terimplementasi secara maksimal di PP Madinatul Ilmi sebagai pondok pesantren modern. Karenanya kegiatan sosialisasi kebijakan Kementerian Agama tentang standarisasi kompetensi pengajian kitab perlu diintensipkan.

Sistem pembelajaran kitab berbahasa Arab yang diterapkan di PP Madinatul Ilmi tampak non formal, meskipun beberapa kitab yang diajarkan, dijadikan sebagai bahan pendukung dalam proses pembelajaran di satuan pendidikan formal yang dinaungi, MTs dan MA. Sistem pembelajaran kitab berbahasa Arab dilakukan dalam bentuk Taklim Idahfi, yang diselenggarakan pada sore hari. Sistem pembelajaran non formal ini berimplikasi pada penilaian hasil pembelajaran yang cenderung sumatif -evaluasi dilakukan dalam rangka memberikan penambahan pemahaman dan keterampilan santri membaca kitab. Realitas ini mengindikasikan bahwa sistem pembelajaran kitab di pesantren tampak masih beragam, formal atau non formal, yang berimplikasi pada sistem evaluasi pembelajaran yang sumatif atau formatif. Karenanya kajian pengembangan dalam rangka merumuskan sistem pembelajaran yang lebih baku agar penerapan standar kompetensi pengajian kitab dapat optimal. Sistem pembelajaran yang dimaksud adalah penentuan standar isi, standar proses pembelajaran, dan standar kelulusan dalam pembelajaran kitab berbahasa Arab.

\section{UCAPAN TERIMA KASIH}

Ucapan terima kasih saya peneliti sampaikan kepada Kepala Balai Penelitian dan Pengembangan Agama Makassar yang telah menugaskan peneliti untuk meneliti implementasi standarisasi pembelajaran kitab berbahasa arab pada pesantren di Sulawesi Tengah. Ucapan yang sama disampaikan kepada pimpinan PP Madinatul Ilmi dan tenaga pengajar kitab berbahasa Arab, yang telah melayani dan meluangkan kesempatan untuk diwawancarai secara mendalam tentang proses pembelajaran di PP Madinatul Ilmi.

\section{DAFTAR PUSTAKA}

A.Qadri A. Azizy. 2004. Profil Pondok pesantren Mu'adalah, Departemen Agama RI, Direktorat Jenderal Kelembagaan dan Pondok Pesantren, Proyek Peningkatan Pondok Pesantren, Jakarta.

An Nawawi. 2001. Dalam Rahim Dkk, Kendali Mutu Pendidikan Agama Islam, Cet. Pertama, Departemen Agama RI Direktorat Jenderal Pembinaan Kelembagaan Agama Islam/Direktorat Pembinaan Pendidikan Agama Islam pada Sekolah Umum Negeri, Proyek peningkatan tenaga teknis Pendidikan Agama Islam, Jakarta.

Arifin. 2001. dalam Rahim Dkk, Kendali Mutu Pendidikan Agama Islam, Cet. Pertama, Departemen Agama RI Direktorat Jenderal Pembinaan Kelembagaan Agama Islam/Direktorat Pembinaan Pendidikan Agama Islam pada Sekolah Umum Negeri, Proyek peningkatan tenaga teknis Pendidikan Agama Islam, Jakarta.

Arsyad, Azhar. Alternatif Pola Partisipasi Masyarakat Terhadap Satuan Pendidikan Keagamaan. Makalah disampaikan atas permintaan Balai 
Penelitian dan Pengembangan Agama di Grand Clarion Hotel 05 Juni 2012

Asrohah, Hanun. 2004. Pelembagaan Pesantren, Asal Usul dan Perkembangan Pesantren di Jawa. Jakarta: Proyek Peningkatan Informasi Penelitian Dan Diklat Keagamaan Departemen Agama,.

Departemen Agama. Pedoman Pondok Pesantren Salafiah (Jakarta: Direktorat Pendidikan Diniyah dan Pondok Pesantren Direktorat Jenderal Pendidikan Islam Departemen Agama, 2009) h.

Departemen Pendidikan Nasional. UndangUndang RI No. 2O Tahun 2003 Tentang Sistem Pendidikan Nasional, Cet, I: Bandung : Fokus Media,2003)

Dewi Ade K. 2001. Kamus praktis Bahasa Indonesia Untuk SLTP, SMU Fajar Mulia, Surabaya.

Dhofier, Zamachsari. 1983. Tradisi Pesantren Studi Tentang Pandangan Hidup Kyai. Jakarta: LP3ES.

Djamarah, Syaiful Bahri Dkk. 1995. Strategi Belajar Mengajar. Banjarmasin: Penerbit Rineka Cipta..

Faiqoh. 2003. Pondok pesantren Dan Madrasah Diniyah Pertumbuhan Dan Perkembangannya, Jakarta: Departemen Agama RI, Direktorat Jenderal Kelembagaan Agama Islam.

Hasan Basri. dalam A. Qadir A.Azizy. 2004. Profil Pondok pesantren Mu'adalah, Jakarta: Departemen Agama RI, Direktorat Jenderal Kelembagaan dan Pondok Pesantren, Proyek Peningkatan Pondok Pesantren.

Hasbullah. 1999. Sejarah Pendidikan Islam di Indonesia: Lintasan Sejarah Pertumbuhan dan Perkembangan. Jakarta: PT Raja Grafindo Persada.

Horne, H, dalam Rahim Dkk. 2001. Kendali Mutu Pendidikan Agama Islam, Cet. Pertama, Jakarta: Departemen Agama RI Direktorat Jenderal Pembinaan Kelembagaan Agama Islam/Direktorat Pembinaan Pendidikan Agama Islam pada
Sekolah Umum Negeri, Proyek peningkatan tenaga teknis Pendidikan Agama Islam.

Mufid, Ahmad Syafii. 2006. Tangklukan, Abangan, dan Tarekat, Kebangkitan Agama Jawa, Jakarta: Yayasan Obor Indonesia.

Rahim dkk. Kendali Mutu Pendidikan Agama Islam, 2001, Cet. Pertama, Jakarta: Departemen Agama RI Direktorat Jenderal Pembinaan Kelembagaan Agama Islam/Direktorat Pembinaan Pendidikan Agama Islam pada Sekolah Umum Negeri, Proyek peningkatan tenaga teknis Pendidikan Agama Islam.

Tafsir, Ahmad. 2007. Metodologi Pengajaran Agama Islam. Cetakan ke sembilan. Bandung: PT. Remaja Rosdakarya.

Yusuf, Khaerulfuat. 2009. Pedoman Pengembangan Kurikulum Pesantren, Cetakan I, Jakarta: Direktorat Pendidikan Diniyah Dan Pondok Pesantren, Direktorat Jenderal Pendidikan Islam Departemen Agama RI.

Zuhairini, et.al. 1997. Sejarah Pendidikan Islam. Jakarta: Bumi Aksara. 